\title{
Being of brine
}

Nancy Merridew, BA, BSc, MBBS

Correspondence

Dr. Merridew

nancy.merridew@gmail.com

This poem explores the essence of cellular pathways to accomplish life as we know it. Biochemistry is extraordinary. It drives physiology, thought, actions, and interactions of organisms in their environments. While other molecules are essential, ions are the functional currency of biological cells, tissues, organs, and systems. Feats and experiences of living beings transpire by the humbling reality of ions cycling across membranes - by passive diffusion and active transport - as part of complex networks.

Hold the thought

that aqueous salts

propel a life of thought.

Salts convey earth and air,

hopes, despair, and plans

of human clans and creatures.

Salts steer helms to every port;

observe their wake and contemplate.

Elements, older than eons,

forged of star, vapour and dust

trade electrons and accrete.

Lipids align and salts dissolve-

ions teem in water,

marshal at membranes,

drift and pump through channels,

seek and defy equilibrium.

Life arrives.

Cells pluck nitrogen from air,

fixed now, for superb amino acid chains.

Pigments seize light to photosynthesise-

yield saccharides,

alter atmospheres,

transform seas and lands;

empower kingdom Animalia.

Simply ionic vessels,

we drift and pump into being.

Salts stream through conduits and matrices

of Nature's splendid molecules,

to choreograph flesh, frame and blood-

Beat, breathe, feed.

Flaunt, move, sense.

Ascend to sentience. 
Thoughts rise on ionic tides of cells and organellescharges ricochet in one mind's depth, cross synapse networks, thence to flex faces, mouths, limbs and fingertips.

Myriad sentiments broadcast to fresh eyes, ears, skin where salts surge to sense, then bring ideas to other minds and muscles.

Salts charge human marionettes with voice of operas and parliaments; tools to farm and sail by stars; dance at corroborees and waltzes; art on Guggenheim walls.

Salts scatter perceptions, conduct taboos of tribes and altars, spark scholarship, industries and wars.
Ionic alchemy, traversing time, stores ideas as latent lines set on pages, pavements, stelae, screensby lines of alphabets and hieroglyphs, compasses, clocks, and maps, numerals and treble clefsBlueprints for salts of future folk to sense, interpret, perpetuate.

Salts of life and earth dispersecourse through emperors, beggars, wolves and crows

to sense, reflex, think and act, wilt or grow, interact.

All achieved by primal brine and evolution's mark in time. 


\title{
Neurology
}

\author{
Being of brine \\ Nancy Merridew \\ Neurology 2020;95;1059-1060 Published Online before print October 1, 2020 \\ DOI 10.1212/WNL.0000000000010956
}

This information is current as of October 1, 2020

Updated Information \&
Services

Subspecialty Collections

Permissions \& Licensing

Reprints including high resolution figures, can be found at: http://n.neurology.org/content/95/23/1059.full

This article, along with others on similar topics, appears in the following collection(s):

All Clinical Neurology

http://n.neurology.org/cgi/collection/all_clinical_neurology

All clinical neurophysiology

http://n.neurology.org/cgi/collection/all_clinical_neurophysiology

All Neuropsychology/Behavior

http://n.neurology.org/cgi/collection/all_neuropsychology_behavior

Information about reproducing this article in parts (figures,tables) or in its entirety can be found online at:

http://www.neurology.org/about/about_the_journal\#permissions

Information about ordering reprints can be found online:

http://n.neurology.org/subscribers/advertise

Neurology ${ }^{\circledR}$ is the official journal of the American Academy of Neurology. Published continuously since 1951 , it is now a weekly with 48 issues per year. Copyright @ 2020 American Academy of Neurology. All rights reserved. Print ISSN: 0028-3878. Online ISSN: 1526-632X.

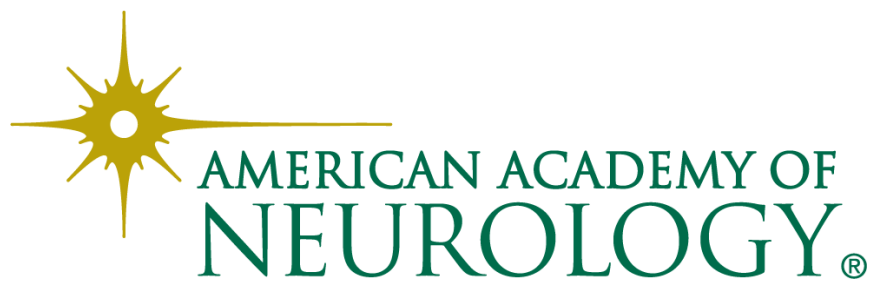

